\title{
KONSEP EKONOMI LAISSEZ FAIRE
}

Mirna Rafki/90100118012

Ekonomi Islam (A) 2018

Perekonomian global yang mengalami kemajuan pada tahun 1990-an berdampak pada kehidupan pasar sosial masyarakat. Masyarakat seolah-olah bersaing dengan masyarakat luar dan masyarakatnya sendiri. Sehingga proses pertumbuhan ekonomi serta pembangunan bangsa terus diusahakan dengan menggunakan paradigma globalisasi ekonomi. Paradigma berprinsip "Laissez Faire" kegiatan perekonomian seluruhnya diserahkan kepada pasar. (Chabibi, 2019). Tidak terdapat campur tangan pemerintah, manusia diberikan kebebasan memberikan yang terbaik untuk dirinya sendiri, hal itulah kemudian yang menjadi doktrin laissez faire-laissez passer (biarkan semua terjadi, biarkan semua berlalu). Maksudnya ialah ekonomi akan berjalan dengan wajar tanpa campur tangan pemerintah, sebab nantinya akan terdapat tangan yang tak terlihat (invisible hand) yang akan membawa ekonomi kearah harga yang seimbang. (Parakkasi, H. Idris, 2018). Prinsip ekonomi laissez faire sendiri diperkenalkan oleh Adam Smith, bahwa pemerintah selaku pemangku kendali politik Negara melakukan campur tangan seminimal mungkin dalam perekonomian. Sehigga seluruh apa yang dilakukan manusia akan berjalan secara damai, otomatis, serta terkendali.(Faruq \& Mulyanto, 2017)

Madzhab klasik dengan semboyan laissez faire ini di tekankan pada pemanfaatan sumber ekonomi yang terbatas yang mempunyai efisiensi yang tinggi untuk menggapi kesejahteraan bersama apabila pemerintah tidak ikut 
campur. Negara tidak berkewajiban melaksanakan intervensi untuk dapat menstabilkan kekayaan karena masalah ekonomi diserahkan seluruhnya ke mekanisme pasar, hal tersebut sesuai dengan pandangan laissez faire. Diawali dari pemikiran Adam Smith pada abad ke-18, laissez faire ialah frasa bahasa prancis yang berarti "biarkan terjadi" istilah tersebut pertama kali digunakan oleh para psiokrat pada abad ke-18 terhadap perlawanannya pada intervensi pemerintah dalam perdagangan. Kemudian pada awal tahun 1930-an pandangan laissez faire mengendur setelah Keynes membenarkan campur tangan pemerintah pada sektor ekonomi.(Rahmawaty, 2013). Karena Idenya yang pro terhadap pasar dan pro terhadap pemerintah, ia menginginkan adanya peranan pemerintah untuk ikut andil dalam perekonomian serta pembangunan suatu negara pada batas tertentu.

Menurut konsep laissez faire, pasar yang paling baik adalah persaingan bebas, dimana harga dibangun oleh kaidah supply and demand. Pasar yang bebas akan memberikan keseimbangan di masyarakat yang menghasilkan upah yang adil, barang yang stabil serta mengurangi pengangguran. Sehingga peran pemerintah dalam ekonomi sangat perlu diminimalisir. sebab apabila pemerintah turut serta campur tangan maka sektor swasta dapat tersingkir dan akan menimbulkan ketidakseimbangan pasar. Paradigma kapitalisme mengenai mekanisme pasar akan menghasilkan keputusan yang adil dan baik dari berbagai kepentingan dipasar. Oleh karena itu para penganut laissez fire mendukung perdagangan bebas. Negara tidak diperkenankan untuk melakukan proteksi seperti subsidi dan tarif diwilayah ekonominya, serta meyakini bahwa pasar adalah sebuah sistem yang mandiri.(Alang, 2018). 


\section{DAFTAR PUSTAKA}

Alang, Agung Zulkarnai. (2018). Mekanisme Pasar Dalam Perspektif Ekonomi Islam. Journal Of Institution And Sharia Finance, I(2), 31-55.

Chabibi, M. (2019). Pertaruhan Politik Negara Atas Mekanisme Pasar ( Studi Analisis Ekonomi Politik Menurut John Rawls ). Indonesian Interdisciplinary Journal Of Sharia Economics, 1(2), 16-28.

Faruq, U. Al, \& Mulyanto, E. (2017). Sejarah Teori-Teori Ekonomi (Issue 1).

Parakkasi, H. Idris, Dan K. (2018). Analisis Harga Dan Mekanisme Pasar Dalam Perspektif Islam. Laa Maysir, 5(1), 112.

Rahmawaty, A. (2013). Distribusi Dalam Ekonomi Islam (Upaya Pemerataan Kesejahteraan Melalui Keadilan Distributif). Equilibrium, 1(1), 1-17. 